\title{
PALEOBIOLOGY OF THE EDIACARA FAUNA
}

RUNNEGAR, Bruce, Department of Earth and Space Sciences, Molecular Biology Institute, and Institute of Geophysics and Planetary Physics, University of California, Los Angeles, CA 90024-1567 U.S.A.

Long regarded as the earliest evidence for animal life, the fossils of the Ediacara fauna have come under increasingly close scrutiny as the result of a proposal made by A. Seilacher in 1983. At that time Seilacher suggested that the Ediacara fauna represents an extinct line of animal life (the Vendozoa) which pioneered a body form and modes of nutrition not seen in the Phanerozoic. More recently, Seilacher and others have suggested that most typical members of the Ediacara fauna were not even animals but were extinct foliate creatures analogous to algae or fungi which relied on endogenous photosymbionts or chemosymbionts for food and energy.

It would not be surprising if the Ediacaran organisms contained bacterial or eukaryotic endosymbionts as endosymbiosis at the organelle or unicell level is the norm rather than the exception for many protists and diploblastic metazoans. However, it is difficult to find the evidence to test this endosymbiont hypothesis because the Ediacaran fossils are merely impressions of soft bodies in sandstone or siltstone.

As there are no clear modern homologs of most of the Ediacaran organisms it is necessary to resort to logic and experiment to understand them. This has proved to be a formidable task but some progress is being made with complex forms such as Dickinsonia and Phyllozoon. Although no core member of the Ediacara fauna is unequivocally an early animal, there are more similarities to animals than to algae or fungi. There is no evidence at all that the vendozoans are fourth form of eukaryotic multicellular life. 